\title{
Lung function and six-minute walk test performance in individuals with sickle cell disease
}

\author{
Daniela G. Ohara ${ }^{1}$, Gualberto Ruas ${ }^{2}$, Isabel A. P. Walsh ${ }^{2}$, \\ Shamyr S. Castro ${ }^{2}$, Mauricio Jamami ${ }^{3}$
}

\begin{abstract}
Background: Sickle Cell Disease (SCD), which is characterized by a mutation in the gene encoding beta hemoglobin, causes bodily dysfunctions such as impaired pulmonary function and reduced functional capacity. Objective: To assess changes in pulmonary function and functional capacity in patients with SCD and to identify the relationships between these variables. Method: We evaluated sociodemographic, anthropometric, lung function (spirometry), respiratory (manovacuometer), peripheral muscle strength (Handgrip strength - HS) and functional capacity (i.e., the six-minute walk test) parameters in 21 individuals with SCD (average age of $29 \pm 6$ years). Shapiro-Wilk, paired Student's, Wilcoxon, Pearson and Spearman correlation tests were used for statistical analyses, and the significance threshold was set at $p<0.05$. Results: A total of $47.6 \%$ of the study subjects exhibited an altered ventilation pattern, $42.8 \%$ had a restrictive ventilatory pattern (RVP) and $4.8 \%$ exhibited a mixed ventilatory pattern (MVP). The observed maximal inspiratory pressure (MIP) values were below the predicted values for women $\left(64 \mathrm{cmH}_{2} \mathrm{O}\right)$, and the maximum expiratory pressure (MEP) values, HS values and distance walked during the 6MWT were below the predicted values for both men (103 $\mathrm{cmH}_{2} \mathrm{O}, 39 \mathrm{Kgf}$ and $447 \mathrm{~m}$, respectively) and women (64 cmH $\mathrm{O}_{2} ; 27 \mathrm{Kgf} ; 405 \mathrm{~m}$, respectively). Positive correlations were observed between maximum voluntary ventilation (MVV) and MEP ( $\mathrm{r}=0.4 ; \mathrm{p}=0.046)$; MVV and BMI ( $\mathrm{r}=0.6$; $\mathrm{p}=0.003)$; and between HS and MIP ( $\mathrm{r}=0.7 ; \mathrm{p}=0.001)$, MEP $(\mathrm{r}=0.6 ; \mathrm{p}=0.002)$, MVV $(\mathrm{r}=0.5 ; \mathrm{p}=0.015)$, distance walked in the 6MWT $(r=0.4 ; p=0.038)$ and BMI ( $\mathrm{r}=0.6 ; \mathrm{p}=0.004)$. Conclusions: SCD promoted changes in lung function and functional capacity, including RVPs and a reduction in the distance walked in the 6MWT when compared to the predictions. In addition, significant correlations between the variables were observed.
\end{abstract}

Keywords: sickle cell anemia; physical therapy; respiratory function tests; spirometry; six-minute walk test.

\section{HOW TO CITE THIS ARTICLE}

Ohara DG, Ruas G, Walsh IAP, Castro SS, Jamami M. Lung function and six-minute walk test performance in individuals with sickle cell disease. Braz J Phys Ther. 2014 Jan-Feb; 18(1):79-87. http://dx.doi.org/10.1590/S1413-35552012005000139

\section{Introduction}

Sickle cell disease (SCD) is a group of hereditary hemolytic anemias that are found frequently throughout the world, including in Brazil ${ }^{1}$. SCD is characterized by a mutation in the gene encoding the beta chain of hemoglobin, which results in a change from the normal hemoglobin conformation (HbA) to the hemoglobin S conformation (HbS). This conformational change can lead to several hemoglobinopathies, including sickle cell anemia (HbSS), HbSC and S-thalassemia, as well as several others with lower incidence ${ }^{2,3}$. Deoxygenated hemoglobin undergoes a polymerization process that induces red blood cells to acquire a sickle-like shape, which results in cell damage and causes systemic organ dysfunction ${ }^{2,4-6}$.
The respiratory system is one of the most affected systems in SCD, and 20 to $30 \%$ of deaths in adults with SCD are due to pulmonary manifestations, which typically occur around the age of 20 and lead to death at approximately 40 years of age ${ }^{3}$. Airway obstructions and repeated pulmonary infections are among the primary causes of pulmonary involvement, and they result in obstructive or restrictive respiratory disorders, which can result in pulmonary hypertension ${ }^{1,3}$. Moreover, this population often presents with acute chest syndrome, which is characterized by chest pain, prostration, cough, dyspnea and hypoxia ${ }^{2}$.

In addition, the systemic impairments caused by SCD can lead to a more sedentary lifestyle, which can

\footnotetext{
${ }^{1}$ Physical Therapy Graduate Program, Universidade Federal de São Carlos (UFSCar), São Carlos, SP, Brazil

${ }^{2}$ Department of Applied Physical Therapy, Institute of Health Sciences (ICS), Universidade Federal do Triângulo Mineiro (UFTM), Uberaba, MG, Brazil

${ }^{3}$ Department of Physical Therapy, UFSCar, São Carlos, SP, Brazil

Received: 04/22/2013 Revised: 08/09/2013 Accepted: 10/02/2013
} 
in turn result in an overall loss of muscle strength and a consequent reduction in functional capacity. Ivo and Carvalho ${ }^{7}$ reported that patients with sickle cell anemia presented dyspnea while walking, climbing stairs or ramps, performing heavy duty physical activities or ambulating quickly, which indicates a loss of functional capacity in this population.

Prior studies have assessed lung function ${ }^{8-11}$ and functional capacity ${ }^{12-14}$ in adults with SCD. However, we are unaware of any studies in the published literature that concomitantly assess pulmonary function, functional capacity and muscle strength to identify potential relationships between these variables and to examine possible damage caused by SCD.

Given the information outlined above and considering that individuals with SCD may lose pulmonary function and functional capacity and that these variables are correlated with each other, the present study aimed to evaluate pulmonary function and functional capacity in patients with SCD. This study also aimed to identify the correlations between these variables.

\section{Method}

\section{Study type}

This study was conducted as a descriptive crosssectional exploratory study utilizing quantitative methodology.

\section{Sample}

The convenience sample was obtained by selecting individuals (both males and females, all of whom were at least 18 years of age) from records accessed at the Regional Blood Center (RBC) of Uberaba in the state of MG, Brazil and the Regional Association of Sickle Cell Disease Patients of Uberaba (Associação Regional dos Falcêmicos de Uberaba - ARFA), Uberaba, state of MG, Brazil.

\section{Inclusion and exclusion criteria}

Individuals over the age of 18 who had received a diagnosis of SCD and who exhibited clinical and hemodynamic stability and the absence of vasoocclusive crisis for at least one month were included in the study. All study subjects agreed to participate and signed an informed consent form prior to being included in the study.
Individuals with lung disease, heart disease, diabetes or musculoskeletal and orthopedic disorders were excluded from the study. In addition, patients with neurological damage that prevented them from performing the proposed tests and those who did not agree to participate or did not sign the informed consent form were also excluded from the study.

\section{Data collection procedures}

Upon agreeing to participate in the study, all individuals signed an informed consent form. Data were collected through individual interviews and physical assessments, which were held on different days and divided into two stages. The first stage collected data related to the participants' sociodemographic characteristics, functional capacity and respiratory muscle strength. The second stage investigated anthropometric characteristics, peripheral muscle strength and pulmonary function. These two stages of the assessment were randomized and divided so that the tests requiring maximum effort were not performed on the same day. This procedure aimed to reduce the risks to the health of the assessed individuals. The assessments were performed by a previously trained physical therapist between March and September of 2012.

\section{Instruments and measures for data collection}

\section{Sociodemographic data}

Sociodemographic data were assessed by an interview, which consisted of a semi-structured questionnaire that obtained data regarding the gender, age, ethnicity / race, marital status, education, occupation, monthly income and medical history of each participant.

\section{Anthropometric data}

The anthropometric data and the body mass index (BMI) were measured using a calibrated anthropometric scale (Filizola ${ }^{\circledR}$ ) while individuals were barefoot and wearing minimal clothing. Body mass was measured in kilograms $(\mathrm{kg})$, and height was measured in meters (m). BMI was calculated by dividing the body weight by the squared height $\left(\mathrm{kg} / \mathrm{m}^{2}\right)$.

\section{Functional capacity}

Functional capacity was assessed using the sixminute walk test (6MWT), which was conducted in 
an outdoor corridor ( $30 \mathrm{~m}$ long by $1.5 \mathrm{~m}$ wide). The temperature and air humidity at the time of each test was recorded using a portable thermo-hygrometer (HT-200 Digital- Instrutherm, São Paulo, State of SP, Brazil), and the test was performed according to the recommendations of the American Thoracic Society ${ }^{15}$.

Prior to each test, individuals remained at rest for at least 10 minutes, and blood pressure, oxygen saturation and heart and respiratory rates were measured. The levels of dyspnea and exertion were also determined using the Borg ${ }^{16}$ scale. The distance walked in the 6MWT (6MWD) was measured in meters and was taken as an indication of each individual's performance in the test. The predicted values were calculated according to the method described by Enright and Sherrill ${ }^{17}$.

\section{Peripheral muscle strength}

Overall muscle strength was assessed by measuring handgrip strength (HS), which was evaluated using a Jamar manual hydraulic dynamometer (model SAEHAN ${ }^{\circledR}$ Hydraulic Hand Dynamometer, Masan 630-728 KOREA). Several published studies have shown that this is a quick and effective method for measuring muscle strength that correlates well with other measures of functional capacity and strength in the extremities ${ }^{18-20}$.

HS measurements were performed according to the recommendations of the American Society of Hand Therapists (ASHT) ${ }^{21}$. Individuals were placed in a sitting position without arm support, with their feet on the floor, shoulders adducted, elbows flexed at a $90^{\circ}$ angle and forearms in a neutral position. Following a verbal command, each individual performed a voluntary maximal isometric contraction of the dominant limb. At least three measurements were obtained from each study participant with a one minute interval between measurements. The mean values were determined and compared to the predicted values ${ }^{22}$.

\section{Respiratory muscle strength}

Respiratory muscle strength was assessed by measuring the maximal inspiratory pressure (MIP) and the maximal expiratory pressure (MEP) using manovacuometry. For this purpose, a properly calibrated Ger-Ar ${ }^{\circledR}$ (São Paulo, Brazil) manovacuometer with scales from -300 to +300 $\mathrm{cm} \mathrm{H}_{2} \mathrm{O}$ that was equipped with a plastic trachea 16 inches long and with an inside diameter of $2.4 \mathrm{~cm}$, a rigid plastic nozzle and a leak orifice (approximately
$2 \mathrm{~mm}$ in diameter) was used to prevent increases in oral cavity pressure induced by contractions of the facial and oropharynx muscles ${ }^{23}$.

All maneuvers were performed using a nose clip while the individual was sitting. Following a verbal stimulus, individuals performed a maximum respiratory effort for three seconds (between three and five times) in an acceptable and reproducible way. When the difference between the obtained measurements from an individual was greater than $10 \%$, a new maneuver was performed and the highest value obtained was considered. The MIP value obtained was preceded by a full expiration near the residual volume, and the PEmax was preceded by a full inspiration next to the total lung capacity $(\mathrm{TLC})^{24}$. The values obtained were compared to the predicted values ${ }^{25}$.

\section{Pulmonary function}

To assess pulmonary function, a properly calibrated microQuark ${ }^{\circledR}$ portable spirometer (COSMED, Rome, Italy) was used according to the technical procedures of the Guidelines of the Brazilian Society of Pulmonology and Phthisiology (Sociedade Brasileira de Pneumologia e Tisiologia) ${ }^{26}$. The following measures were obtained: slow vital capacity (SVC), forced vital capacity (FVC), forced expiratory volume in one second $\left(\mathrm{FEV}_{1}\right)$, the $\mathrm{FEV}_{1} / \mathrm{FVC}$ ratio and the maximum voluntary ventilation (MVV). Two minute intervals separated each of the FVC, SVC and MVV measurements, and at least three replicates were obtained for each maneuver, except for MVV, for which only a single measurement was obtained. Spirometric values were expressed as a percentage of the predicted value for the Brazilian population ${ }^{26}$.

\section{Data analysis}

Descriptive analyses were performed to determine the means, standard deviations, absolute numbers and percentages. Shapiro-Wilk tests, which were used to verify the normality of the data, revealed that all variables in the current study sample had normal distributions, except for MIP.

Paired Student's t-tests were used to compare the measured and predicted values for MEP, lung volume and capacity, 6MWD and HS, and the Wilcoxon test was used for MIP. Because only one of the variables exhibited a non-parametric distribution, we have presented all data as the means and standard deviations. To study the correlations between the variables, Pearson tests were used for MEP, lung volume and capacity, 6 MWD and HS, and Spearman tests were used for MIP. Correlations were classified 
as weak ( 0.26 to 0.49$)$, moderate ( 0.50 to 0.69$)$, strong $(0.70$ to 0.89$)$ or very strong $(0.90 \text { to } 1.00)^{27}$. The significance level was set at $\mathrm{p}<0.05$. The Statistical Package for Social Sciences (SPSS), version 17.0 for Windows, was used for statistical analyses.

\section{Ethical aspects of the study}

The project was approved by the Research Ethics Committee of the Federal University of Triangulo Mineiro (Universidade Federal do Triângulo Mineiro - UFTM), of Uberaba, state of MG, Brazil, under protocol No. 1818. All participants were informed of the objectives and methodology of the study, and they all signed informed consent forms in accordance with Resolution No. 196 of October 10, 1996 of the National Board of Health (Conselho Nacional de Saúde).

\section{Results}

From the survey of records accessed in the RBC and ARFA of Uberaba, 65 individuals were selected. From these, 36 were excluded either because they exhibited comorbidities or they were no longer living at the time of the study. Thus, the initial sample was composed of 29 individuals, of whom eight refused to participate, leaving a final sample size of 21 subjects (Figure 1).

Of the 21 subjects included in the study, 14 $(66.7 \%)$ were male, and seven $(33.3 \%)$ were female. The overall mean age was $29 \pm 6$ years. Most participants were of black ethnicity (66.7\%) and had an average education (47.6\%), active job $(66.7 \%)$ and low income $(66.7 \%$, defined as less than three times the minimum wage). In addition, $66.6 \%$ had the homozygous SS form, $23.8 \%$, had the heterozygous $\mathrm{SC}$ from and $9.6 \%$ had the heterozygous $\mathrm{S} \beta$ form of beta hemoglobin. Regarding medication, all patients were using folic acid, and only four (19\%) used Hydroxyurea.

The demographic and anthropometric characteristics and the spirometric values are presented in Table 1.

During the assessments of lung function, $47.6 \%$ $(n=10)$ of the patients were shown to exhibit an altered ventilatory pattern, and $42.8 \%(\mathrm{n}=9)$ had RVPs. In $4.8 \%(n=1)$ of the patients, the respiratory pattern was both obstructive and restrictive (i.e., mixed). The remaining $52.4 \%$ had preserved lung function.

Regarding respiratory muscle strength, the MIP values were significantly lower than expected for females, but the values observed in males were similar to the reference values for their age. The MEP values were significantly lower than expected for both men and women, as were the HS and 6MWD values, as described in Table 2.

Positive correlations between MVV and MEP (weak) and between MVV and BMI (moderate) were observed. Both maximal respiratory pressures were positively correlated with HS, which was also strongly correlated with MIP and moderately correlated with MEP. Furthermore, HS was observed to correlate positively with 6MWD (weak), MVV and BMI (moderate) (Table 3).

\section{Discussion}

SCD can affect many body systems, including the respiratory and musculoskeletal systems ${ }^{2}$, which can impair lung function and functional capacity. As described above, decreases in lung function, overall muscle strength and functional capacity were observed in the present study.

When assessing pulmonary function, individuals may exhibit either normal function or altered ventilatory patterns, which are classified as obstructive, restrictive or mixed. Obstructive ventilatory patterns (OVPs) are characterized by disproportionately decreased peak flows when compared to the volume that can be eliminated, and the $\mathrm{FEV}_{1}$ and $\mathrm{FEV}_{1} / \mathrm{FVC}$ are the major measures by

Table 1. Distribution of mean demographic, anthropometric and spirometric variables.

$\begin{array}{cc}\text { Variables } & \\ \text { Gender (M/F) } & 14 / 7 \\ \text { Age (years) } & 29 \pm 6 \\ \text { Weight (kg) } & 60 \pm 9 \\ \text { Height (cm) } & 167 \pm 8 \\ \text { BMI (kg/m²) } & 21 \pm 2 \\ \text { FVC (\%pred) } & 79 \pm 9 \\ \text { SVC (\%pred) } & 77 \pm 10 \\ \text { FEV }_{1}(\% \text { pred }) & 79 \pm 7 \\ \text { FEV }_{1} / \text { FVC (\%) } & 99 \pm 11 \\ \text { MVV (\%pred) }^{2} & 68 \pm 13\end{array}$

$\mathrm{Kg}$ : kilogram; cm: centimeter; $\mathrm{Kg} / \mathrm{m}^{2}$ : kilogram per square meter BMI: body mass index; FVC: forced vital capacity; SVC: slow vital capacity, $\mathrm{FEV}_{1}$ : forced expiratory volume in one second; $\mathrm{FEV}_{1} / \mathrm{FVC}$ Ratio between the $\mathrm{FEV}_{1}$ and the FVC; MVV: maximal voluntary ventilation; $\%$ pred: percentage of predicted. 


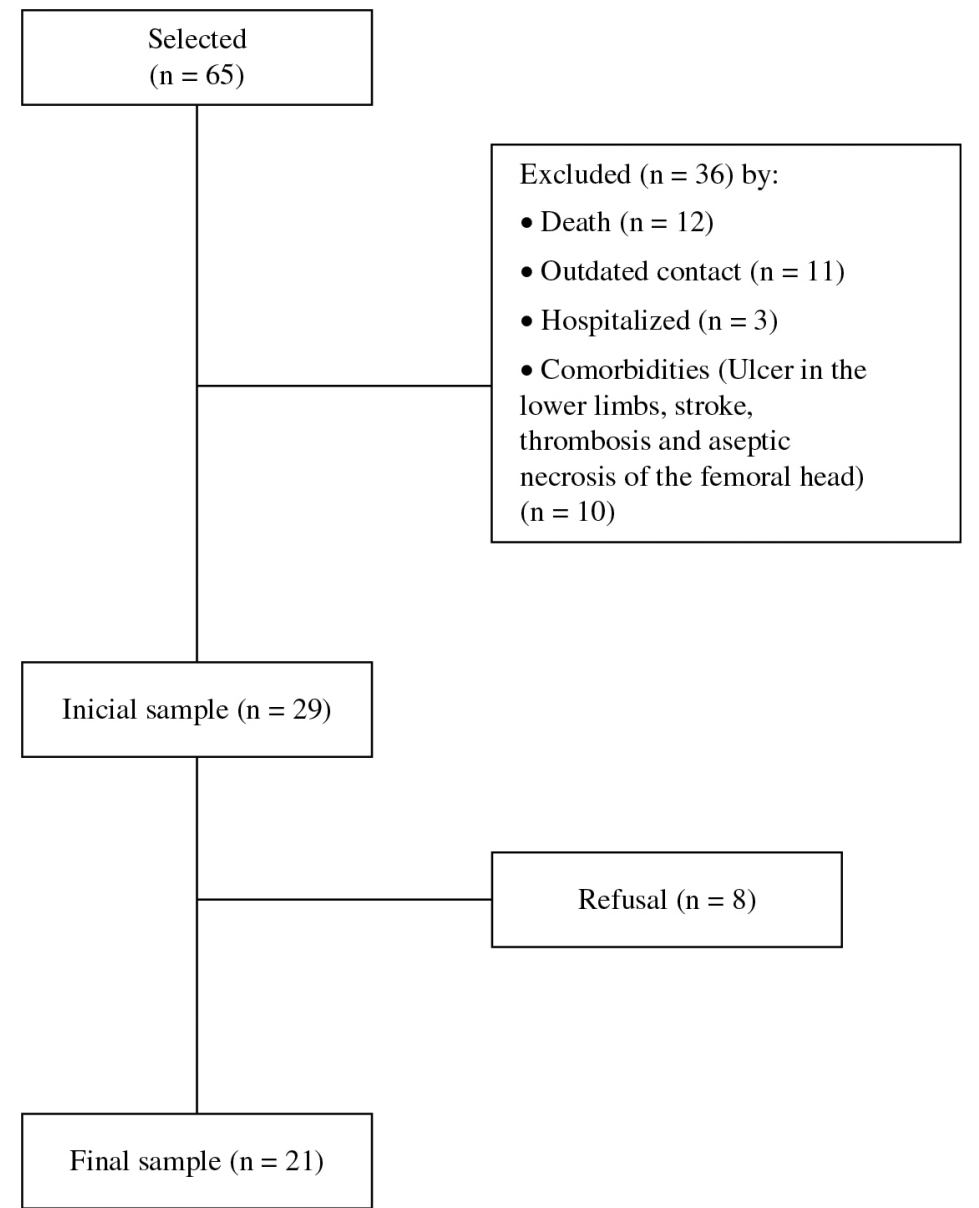

Figure 1. Flow diagram of the representative sample loss and individuals participating in the study.

Table 2. Average values and predicted maximal respiratory pressures, handgrip strength and $6 \mathrm{MWD}$ according to gender.

\begin{tabular}{ccc}
\hline Variables & Obtained (M/F) & Predicted (M/F) \\
MIP $\left(\mathrm{cmH}_{2} \mathrm{O}\right)$ & $100 \pm 28 / 64 \pm 13^{*}$ & $93 \pm 5 / 93 \pm 2$ \\
MEP $\left(\mathrm{cmH}_{2} \mathrm{O}\right)$ & $103 \pm 27^{\#} / 64 \pm 17^{\#}$ & $143 \pm 5 / 94 \pm 2$ \\
$\mathrm{HS}(\mathrm{kgf})$ & $39 \pm 7^{\#} / 27 \pm 7^{\#}$ & $45 \pm 1 / 33 \pm 1$ \\
WD (m) & $447 \pm 62^{\#} / 405 \pm 71^{\#}$ & $731 \pm 61 / 683 \pm 30$ \\
\hline
\end{tabular}

Data are expressed as the mean \pm standard deviation; $(\mathrm{M} / \mathrm{F})$ : (Male/Female) MIP: maximal inspiratory pressure, MEP: maximal expiratory pressure; HS: handgrip strength, WD: walked distance; $\mathrm{cmH}_{2} \mathrm{O}$ : centimeters of water; kgf: kilogram force, m: meters; *: Wilcoxon test, $\mathrm{p}<0.05$; \#: paired Student's t-test, $\mathrm{p}<0.05$.

which to characterize OVPs. RVPs are characterized by decreased TLC. It should be noted that RVP cannot be measured by spirometry. However, RVP values can be inferred when the vital capacity (VC) and FVC are decreased and the $\mathrm{FEV}_{1} / \mathrm{FVC}$ ratio is normal or increased. Finally, MVP is characterized by having both obstruction and restriction simultaneously ${ }^{26}$.

In the present study, the values obtained from $47.6 \%$ of the patients revealed changes in the pulmonary function (i.e., RVP or MVP). Our results indicate that RVP is a common finding in this disease, which is consistent with the results of a study by Klings et al. ${ }^{9}$ that assessed lung function in individuals with SCD in the presence or absence of a history of acute chest syndrome (ACS). In that previous study, most individuals exhibited an RVP, regardless of their history of SCD (77\% of individuals with SCD and 69\% of individuals without SCD).

The presence of RVP in this population might result from episodes of vaso-occlusion in the lung, which is an organ that is prone to suffer from this condition because of its anatomical characteristics ${ }^{28}$. This can result in pulmonary infarctions, necrosis of the alveolar wall with consequent airway remodeling ${ }^{29}$, pulmonary fibrosis and progressive 
Table 3. Distribution of correlation coefficients between MIP, MEP, MVV, BMI, handgrip strength and walked distance.

\begin{tabular}{ccc}
\hline Variables & $\begin{array}{c}\text { Correlation } \\
\text { coefficient (r) }\end{array}$ & $\mathbf{p}$ \\
MIP vs. HS & $0.7^{*}$ & 0.001 \\
MIP vs. MVV & $0.3^{*}$ & 0.079 \\
MIP vs. BMI & $0.2^{*}$ & 0.352 \\
MEP vs. MVV & $0.4^{* *}$ & 0.046 \\
MEP vs. HS & $0.6^{* *}$ & 0.002 \\
MEP vs. BMI & $0.1^{* *}$ & 0.452 \\
MVV vs. HS & $0.5^{* *}$ & 0.015 \\
WD vs. MVV & $0.03^{* *}$ & 0.884 \\
WD vs. HS & $0.4^{* *}$ & 0.038 \\
BMI vs. MVV & $0.6^{* *}$ & 0.003 \\
BMI vs. HS & $0.6^{* *}$ & 0.004 \\
\hline
\end{tabular}

MIP: maximal inspiratory pressure, MEP: maximal expiratory pressure; HS: handgrip strength; MVV: maximal voluntary ventilation, WD: walked distance; BMI: body mass index; vs.: versus; *: Spearman correlation; **: Pearson correlation.

loss of lung function ${ }^{30,31}$. In addition, RVP may be a result of shallow breathing caused by chest pain or by structural impairments of the chest cavity due to bone infarcts, osteoporosis or osteomalacia in the vertebrae ${ }^{3}$.

These changes affect both lung elasticity and the expansion of the chest wall ${ }^{32,33}$, two factors that may also influence respiratory muscle strength. In the present study, the observed respiratory muscle strength was weak because women had reduced MIP and MEP values and men had reduced MEP values when compared to the predicted values ${ }^{25}$. In a recent study $^{11}$, the respiratory muscle strength (MIP and MEP) of 34 children and adolescents (with a mean age of $12.9 \pm 3.5$ years) with SCD was evaluated. That recent study reported weakness in the expiratory muscles, thus suggesting that patients can suffer the consequences of SCD even in this age range. Although the age range of this study differs from that examined in the present study, we observed that the weakness of the expiratory muscles may persist into adulthood and that inspiratory muscles may also be affected in women.

When assessing the relationships between respiratory muscle strength and lung function, a positive correlation between MEP and MVV was observed, which represents the individual's ability to sustain a high level of ventilation ${ }^{26}$ (i.e., the strength of the respiratory muscles) ${ }^{34}$. To sustain a high level of ventilation, it is important that the respiratory muscles maintain their strength, which highlights the relationship between these two components. Thus, when planning physical therapy, resistance training should be performed in addition to strength training of the respiratory muscles to allow for the maintenance of constant breathing patterns with some resistance ${ }^{35}$. Including resistance training can help prevent early fatigue and dyspnea, thereby providing a greater tolerance for physical exercise.

In addition to changes in respiratory muscle strength, a discrete reduction in the strength of the peripheral muscles was identified, as demonstrated by the HS values. This muscle weakness may be the result of the pathophysiology of SCD, in which individuals have frequent vaso-occlusive crises $^{4}$ due to the process of $\mathrm{HbS}$ polymerization, which promotes greater adhesion of these cells to the vascular endothelium and can induce ischemia, inflammation and oxidative stress ${ }^{30}$. It is known that oxidative stress can damage peripheral muscle, thus leading to impaired performance and function ${ }^{36}$.

The observed changes in peripheral muscle strength may be related to the strength and resistance of the respiratory muscles, which are represented by the maximal respiratory pressures and MVV, respectively, as shown in the present study, in which HS was shown to correlate with MIP, MEP and MVV.

In addition, the decreased functional capacity of this population may result from the systemic involvement reported in this population ${ }^{2}$, which includes dyspnea, fatigue, lower limb pain and generalized muscle weakness ${ }^{37}$. These are consistent with the results of the present study, in which functional capacity was reduced when compared to the expected value for the 6MWT. In a study ${ }^{12}$ conducted with SCD patients with and without pulmonary hypertension, individuals who did not have pulmonary hypertension walked an average of 435 meters in the 6MWT, which is very similar to the distance walked in the present study, in which subjects walked an average of 426 meters. Barst and colleagues ${ }^{14}$ also evaluated functional capacity in adults with SCD, but only in patients with SCD that was associated with arterial or venous pulmonary hypertension. In addition, the distance walked was 353 and 370 meters for patients with arterial and venous pulmonary hypertension, respectively, both of which are lower values for 6MWTs than those observed in the present study. 
One factor that may have contributed to the impaired functional capacity observed in the present study is the presence of recurring pain that can arise from SCD, especially in regions of the hip and lower $\operatorname{limb}^{38}$. Chronic pain may involve changes in the functional state ${ }^{39}$ and predispose affected individuals to a more sedentary lifestyle. This can result in less muscular work and a consequent decrease in tropism that can lead to peripheral muscle weakness over time $^{40}$, which compromises functional capacity, as observed in this study, in which the HS was related to 6MWD.

Furthermore, the chronic hemolysis observed in individuals with SCD results in increased metabolic demand due to increased erythropoiesis and cardiac work, which causes a greater demand for energy, minerals and proteins. Thus, the basal metabolic rate of these individuals is $20 \%$ higher than that observed in healthy controls, a fact that frequently leads to lower BMI values ${ }^{1}$, as observed in the present study. This factor may cause reduced muscle strength and changes in pulmonary function, which would be consistent with the results of the present study, in which BMI was positively correlated with HS and MVV. However, the changes in BMI and other variables studied herein are the result of SCD and comprise a symptomatology that involves interactions between all of these factors.

The primary limitation of the present study is the small sample size, which resulted from the fact that many individuals were not included because of their associated comorbidities (or death prior to the study), hospitalizations, outdated contact information or their refusal to participate in the study. However, it is difficult to perform studies of SCD with large sample sizes because of the low frequency of SCD when compared to other chronic diseases. Moreover, the lack of studies examining similar objectives in individuals within a similar age range made it difficult to compare the results obtained in this study. However, our results suggest a new perspective regarding the effects of SCD on pulmonary function and functional capacity, at least within the sample studied here.

\section{- Conclusion}

Individuals with SCD may exhibit changes in pulmonary function and functional capacity. Indeed, the MIP observed in women examined in the current study was lower than expected. The MEP, HS and $6 \mathrm{MWD}$ values were all lower than expected among both men and women. Finally, positive correlations were observed between HS and the MEP, MIP, MVV, BMI and 6MWD. Positive correlations were also observed between the MVV and MEP and BMI.

These results suggest that damage caused by SCD can significantly impact pulmonary function and functional capacity. Thus, adequate measures for intervention should be encouraged, especially physical therapy, which could play an important role in improving the health of this population.

\section{Acknowledgements}

Regional Blood Center of Uberaba, MG, Brazil and Regional Association of Sickle Cell Disease Patients of Uberaba, MG, Brazil.

\section{References}

1. Agência Nacional de Vigilância Sanitária - ANVISA. Manual de diagnóstico e tratamento de doença falciforme. Brasília: ANVISA; 2002.

2. Brasil. Ministério da Saúde. Secretaria de Atenção à Saúde. Departamento de Atenção Especializada. Manual de eventos agudos em doença falciforme. Brasília: Editora do Ministério da Saúde; 2009. 50 p.

3. Moreira GA. Respiratory repercussions of sickle cell anemia. Jornal Brasileiro de Pneumologia: publicação oficial da Sociedade Brasileira de Pneumologia e Tisilogia. 2007;33(3):18-20. PMid:17906782.

4. Zago MA, Pinto ACS. Fisiopatologia das doenças falciformes: da mutação genética à insuficiência de múltiplos órgãos. Rev Bras Hematol Hemoter. 2007;29:20714. http://dx.doi.org/10.1590/S1516-84842007000300003

5. Lobo C, Marra VN, Silva RMG. Crises dolorosas na doença falciforme. Rev Bras Hematol Hemoter. 2007;29:247-58. http://dx.doi.org/10.1590/S1516-84842007000300011

6. Silva IA. Atuação fisioterapêutica na anemia falciforme. Lato \& Sensu. 2003;4(1):3-5.

7. Ivo ML, Carvalho ECd. Assistência de enfermagem a portadores de anemia falciforme, à luz do referencial de Roy. Rev Lat Am Enfermagem. 2003;11:192-8. http:// dx.doi.org/10.1590/S0104-11692003000200008

8. Santoli F, Zerah F, Vasile N, Bachir D, Galacteros F, Atlan G. Pulmonary function in sickle cell disease with or without acute chest syndrome. Eur Respir J. 1998;12(5):1124-9. PubMed PMID: 9864008. http:// dx.doi.org/10.1183/09031936.98.12051124

9. Klings ES, Wyszynski DF, Nolan VG, Steinberg MH. Abnormal Pulmonary Function in Adults with Sickle Cell Anemia. Am J Respir Crit Care Med. 2006;173(11):12649. PMid:16556694. PMcid:2662970.

10. Fonseca CSV, Araújo-Melo CA, Carvalho RM, BarretoNeto J, Araújo JG, Cipolotti R. Função pulmonar em portadores de anemia falciforme. Rev Paul Pediatr. 2011;29(1):85-90. http://dx.doi.org/10.1590/ S0103-05822011000100014 
11. Ong BA, Caboot J, Jawad A, McDonough J, Jackson T, Arens R, et al. Respiratory muscle force and lung volume changes in a population of children with sickle cell disease. British J Haematol. 2013;163(1):112-7. http://dx.doi. org/10.1111/bjh.12481

12. Anthi A, Machado RF, Jison ML, Taveira-Dasilva AM, Rubin LJ, Hunter L, et al. Hemodynamic and functional assessment of patients with sickle cell disease and pulmonary hypertension. Am J Respir Crit Care Med. 2007;175(12):1272-9. PMid:17379852. PMcid:2176091.

13. Liem RI, Nevin MA, Prestridge A, Young LT, Thompson AA. Functional capacity in children and young adults with sickle cell disease undergoing evaluation for cardiopulmonary disease. Am J Hematol. 2009;84:645-9. http://dx.doi.org/10.1002/ajh.21507

14. Barst RJ, Mubarak KK, Machado RF, Ataga KI, Benza RL, Castro O, et al. Exercise capacity and haemodynamics in patients with sickle cell disease with pulmonary hypertension treated with bosentan: results of the ASSET studies. British J Haematol. 2010;149(3):426-35. http:// dx.doi.org/10.1111/j.1365-2141.2010.08097.x

15. ATS Committee on Proficiency Standards for Clinical Pulmonary Function Laboratories. ATS statement: guidelines for the six-minute walk test. Am J Respir Crit Care Med. 2002;166(1):111-7. PMid:12091180. PMid:12091180.

16. Borg GAV. Psychophysical bases of perceived exertion. Med Sci Sport Exer. 1982;14(5): 377-81. PMid: WOS: A1982PP69300010. PMid:WOS:A1982PP69300010.

17. Enright PL, Sherrill DL. Reference equations for the sixminute walk in healthy adults. Am J Respir Crit Care Med. 1998;158(5 Pt 1):1384-7. PMid:9817683.

18. Moreira D, Alvarez RRA, Gogoy JR, Cambraia AN. Abordagem sobre preensão palmar utilizando o dinamômetro Jamar ${ }^{\circledR}$ : uma revisão de literatura. Rev Bras Ciênc Mov. 2003;11(2):95-9.

19. Sayers SP, Guralnik JM, Thombs LA, Fielding RA. Effect of leg muscle contraction velocity on functional performance in older men and women. J Am Geriatr Soc. 2005;53(3):467-71. PMid:15743291.

20. Wind AE, Takken T, Helders PJM, Engelbert RHH. Is grip strength a predictor for total muscle strength in healthy children, adolescents and young adults? Eur J Pediatr. 2010;169:281-7. http://dx.doi.org/10.1007/ s00431-009-1010-4

21. Fess EE. Grip strength. In: Casanova JS, editor. Clinical assessment recommendations. 2nd ed. Chicago: American Society of Hand Therapists; 1992. p. 41-45.

22. Caporrino FA, Faloppa F, Santos JB, Réssio C, Soares FH, Nakachima LR, et al. Estudo populacional da força de preensão palmar com dinamômetro Jamar ${ }^{\circledR}$. Rev Bras Ortop. 1998;33:150-4.

23. Supinski G. Determination and interpretation of inspiratory and expiratory pressure measurements. Clin Pulm Med. 1999;6:118-25. http://dx.doi. org/10.1097/00045413-199903000-00005

24. American Thoracic Society, European Respiratory Society: ATS/ERS Statement on Respiratory Muscle Testing. Am J Respir Crit Care Med. 2002;166:518-624. http://dx.doi.org/10.1164/rccm.166.4.518
25. Neder JA, Andreoni S, Lerario MC, Nery LE. Reference values for lung function tests: II. Maximal respiratory pressures and voluntary ventilation. Braz J Med Biol Res. 1999;32:719-27. http://dx.doi.org/10.1590/ S0100-879X1999000600007

26. Sociedade Brasileira de Pneumologia e Tisiologia. Diretrizes para testes de função pulmonar. J Pneumol. 2002;28(Suppl 3): S1-82.

27. Munro BH. Statisticals methods for health care research. $4^{\mathrm{a}}$ ed. Philadelphia: Lippincott; 2001.

28. Gualandro SFM, Fonseca GHH, Gualandro DM Complicações cardiopulmonares das doenças falciformes. Rev Bras Hematol Hemoter. 2007;29:291-8. http://dx.doi. org/10.1590/S1516-84842007000300020

29. Delclaux C, Zerah-Lancner F, Bachir D, Habibi A, Monin JL, Godeau B, et al. Factors associated with dyspnea in adult patients with sickle cell disease. Chest. 2005;128(5):3336-44. http://dx.doi.org/10.1378/ chest.128.5.3336

30. Machado RFP. Hipertensão arterial pulmonar associada à anemia falciforme. J Bras Pneumol. 2007;33:583-91. http://dx.doi.org/10.1590/S1806-37132007000500015

31. Morris CR. Asthma management: Reinventing the wheel in sickle cell disease. Am J Hematol. 2009;84(4):234-41. PMid:19229984.

32. Mesa Cuervo JR, Chagéz Leyva O, Hechavarria Miyares J, Placencia Ternblóm A, Losada Buchillón R, Rodríguez LR, et al. Modificaciones funcionales ventilatorias en pacientes con anemia drepanocítica y antecedentes de síndrome torácico agudo. Rev Cuba Hematol Inmunol Hemoter. 2002;18(2).

33. Sylvester KP, Patey RA, Milligan P, Dick M, Rafferty GF, Rees D, et al. Pulmonary function abnormalities in children with sickle cell disease. Thorax. 2004;59:6770. PMCid:PMC1758855. http://dx.doi.org/10.1164/ rccm.200601-1250C

34. Fregonezi G, Resqueti VR, Cury JL, Paulin E, Brunetto AF. Variação diurna de parâmetros de função pulmonar e de força muscular respiratória em pacientes com DPOC. J Bras Pneumol. 2012;38(2):257-63. http://dx.doi. org/10.1590/S1806-37132012000200016

35. Colman ML, Beraldo PC. Estudo das variações de pressão inspiratória máxima em tetraplégicos, tratados por meio de incentivador respiratório, em regime ambulatorial. Rev Fisioter Mov. 2010;23:439-49. http://dx.doi.org/10.1590/ S0103-51502010000300011

36. Dourado VZ, Tanni SE, Vale AS, Faganello MM, Sanchez FF, Godoy I. Manifestações sistêmicas na doença pulmonar obstrutiva crônica. J Bras Pneumol. 2006;32(2):161-71. PMid:17273586.

37. Johansen KL. Exercise and chronic kidney disease: current recommendations. Sports Med. 2005;35(6):48599. PMid: 15974634.

38. Ohara DG, Ruas G, Castro SS, Martins PR, Walsh IA. Musculoskeletal pain, profile and quality of life of individuals with sickle cell disease. Rev Bras Fisioter. 2012;16(5):431-8. PMid:22886311. PMid:22886311. http://dx.doi.org/10.1590/S1413-

39. Taylor LE, Stotts NA, Humphreys J, Treadwell MJ, Miaskowski C. A review of the literature on the multiple 
dimensions of chronic pain in adults with sickle cell disease. J Pain Symptom Manage. 2010;40(3):416-35. PubMed PMID: 20656451. PMcid:2989986.

40. Jagoe RT, Engelen MP. Muscle wasting and changes in muscle protein metabolism in chronic obstructive pulmonary disease. Eur Respir J Suppl. 2003;46:52s-63s. PMid:14621107.

\section{Correspondence}

\section{Daniela Gonçalves Ohara}

Universidade Federal de São Carlos (UFSCar)

Departamento de Fisioterapia

Laboratório de Espirometria e Fisioterapia Respiratória

Rod. Washington Luiz, Km 235

CEP 13565-905, São Carlos, SP, Brazil

e-mail: ohara.daniela@yahoo.com 